\title{
Electrochemical Detection of Hydroquinone by Square Wave Voltammetry using a Zn Layered Hydroxide-Ferulate (ZLH-F) Modified MWCNT Paste Electrode
}

\author{
Mohamad Syahrizal Ahmad ${ }^{1,2}$, Illyas Md Isa ${ }^{1,2, *}$, Norhayati Hashim ${ }^{1,2}$, Mohamad Saufi Rosmi ${ }^{1,2}$, \\ Suzaliza Mustafar ${ }^{1,2}$ \\ ${ }^{1}$ Department of Chemistry, Faculty of Science and Mathematics, Sultan Idris Education University, \\ 35900 Tanjong Malim, Perak, Malaysia \\ ${ }^{2}$ Nanotechnology Research Centre, Faculty of Science and Mathematics, Sultan Idris Education \\ University, 35900 Tanjong Malim, Perak, Malaysia \\ *E-mail: illyas@ @smt.upsi.edu.my
}

doi: $10.20964 / 2018.01 .31$

Received: 14 September 2017 / Accepted: 28 October 2017 / Online Published: 1 December 2017

In this paper, a multiwall carbon nanotubes (MWCNT) paste electrode modified by a Zn layered hydroxide-ferulate (ZLH-F) was used for detection of hydroquinone (HQ). The morphology and characteristic of the ZLH-F/MWCNT was investigated by scanning electron microscope (SEM), transmission electron microscope (TEM) and square wave voltammetry (SWV). Under optimal conditions, the SWV response showed linear plot for HQ concentration in the range of $1.0 \times 10^{-5} \mathrm{M}-$ $1.0 \times 10^{-3} \mathrm{M}$. The detection limit was found to be $5.7 \times 10^{-6} \mathrm{M}$ and correlation coefficient of 0.9957 . The glucose, fructose, sucrose, bisphenol A, acetaminophen, lysine, $\mathrm{NO}_{3}^{-}, \mathrm{Cl}^{-}$and $\mathrm{SO}_{4}{ }^{2-}$ did not interfere the HQ response. This modified electrode can be used to determine HQ content in wastewater and cosmetic cream with range of recovery $97.8 \%-103.0 \%$.

Keywords: 1,4-dihydroxybenzene, hydroquinone, multiwall carbon nanotubes, square wave voltammetry.

\section{$\underline{\text { FULL TEXT }}$}

(C) 2018 The Authors. Published by ESG (www.electrochemsci.org). This article is an open access article distributed under the terms and conditions of the Creative Commons Attribution license (http://creativecommons.org/licenses/by/4.0/). 